\title{
Pengaruh akuntabilitas, transparansi, dan partisipasi Terhadap kinerja anggaran berbasis value for money
}

\author{
Detasya Rigian, Ratna Purnama Sari \\ Universitas PGRI Yogyakarta \\ Email. detasyarigian@gmail.com
}

\begin{abstract}
The purpose of the research to test the effect of accountability, transparency, participation, and supervision on the performance of budget based on the value for money in OPD Sleman Regency. The research sample are 101 respondents. The result shows that accountability, transparency, and participation has a significant effect on the performance of budget based on the value for money while supervision has no significant impact on the performance of budget based on the value for money.
\end{abstract}

Keywords: Accountability; transparency; participation; supervision

\section{Latar belakang}

Sistem pengelolaan keuangan yang transparan, akuntabel serta sesuai dengan peraturan perundang-undangan yang berlaku merupakan tuntutan masyarakat akan diterapkannya transparansi dan akuntabilitas. Hal ini wajib diterapkan karena adanya perubahan desentralisasi pengelolaan pemerintahan daerah. Good Corporate Governance adalah syarat utama bagi pemerintah baik pusat maupun daerah dalam mewujudkan harapan masyarakat dan tercapainya tujuan organisasi. Pemerintah pusat maupun daerah yang menerapkan prinsip Good Corporate Governance diharapkan mampu berjalan maksimal dan memperhatikan aspek keadilan, kewajaran, dan manfaat berkelanjutan untuk masyarakat (Jayanti, 2014).

Konsep value for money yang terdapat dalam penerapan anggaran berbasis kinerja didasarkan pada tiga indikator utama yaitu ekonomi, efisien, dan ekonomi (Karacan and Yazici, 2015). Pengelolaan keuangan publik menekankan untuk diwujudkannya kinerja anggaran berbasis value for money. Pelaksanaan sistem akuntabilitas tidak berjalan baik dan maksimal menandakan adanya indikasi penyalahgunaan dan penyelewengan anggaran yang dirahasiakan dari publik (Basri and Nabiha, 2016). Partisipasi dan pengawasan baik secara internal maupun eksternal menjadi aspek pendukung kualitas kinerja yang baik pada pelaksanaan mekanisme akuntabilitas dalam proses penganggaran (Husaini and Lisnawati, 2013).

Penelitian ini menggunakan empat prinsip Good Corporate Governance, karena masih ada penelitian sebelumnya dengan hasil yang belum konsisten. Penelitian yang dilakukan Premananda and Latrini (2017) menemukan bahwa akuntabilitas, transparansi, dan partisipasi berpengaruh terhadap kinerja anggaran berbasis value for money. Didukung oleh penelitian Pertiwi (2015) variabel independen yaitu akuntabilitas, transparansi dan pengawasan berpengaruh positif dan signifikan terhadap variabel dependen yaitu pengelolaan anggaran berbasis value for money. Penelitian yang dilakukan Arifani, A, Salle \& A. Rante (2018) dan Adiwirya and Sudana (2015) menyimpulkan bahwa akuntabilitas tidak berpengaruh terhadap kinerja anggaran berbasis value for money, sedangkan 
transparansi dan pengawasan berpengaruh terhadap kinerja anggaran berbasis value for money.

\section{Kajian teori}

\subsection{Kinerja Anggaran}

Peraturan Pemerintah No. 58 Tahun 2005 Pasal 1 ayat 35 menyatakan bahwa kinerja adalah hasil dari penggunaan anggaran dari kegiatan/program dan aktivitas yang telah dicapai yang diukur dengan jumlah dan kadar mutu. Secara teoritis, prinsip anggaran berbasis kinerja adalah suatu pertanggungjawaban anggaran sehingga setiap biaya yang dikeluarkan dapat dimanfaatkan sebaik mungkin dengan cara menggabungkan antara anggaran negara dengan hasil yang diinginkan (output dan outcome). Tujuan dirancangnya performance based budgeting untuk menciptakan proses pemanfaatan anggaran belanja publik yang efisien, efektif, ekonomis, dan tidak melupakan tujuan awal fokus pada prioritas utama yakni kepentingan masyarakat (Arista and Suartana, 2016).

\subsection{Akuntabilitas}

Akuntabilitas adalah tindakan pertanggungjawaban untuk mencapai tujuan secara berkala pada pelaksanaan kebijakan pengelolaan potensi sumber daya yang dipercayakan pada suatu organisasi (PP No. 71 Tahun 2010 tentang Standar Akuntansi Pemerintah). Akuntabilitas adalah kunci sukses organisasi pada pelaksanaan kebijakan sistem penganggaran sehingga mampu mempertahankan kepercayaan publik (Rawlins,2008).

\subsection{Transparansi}

Peraturan Pemerintah No. 71 Tahun 2010 tentang SAP, "Transparansi berarti wujud pemberian informasi keuangan yang terbuka dan jujur kepada masyarakat luas berdasarkan pertimbangan bahwa masyarakat memiliki hak untuk mengakses secara terbuka dan menyeluruh atas pertangggungjawaban pemerintah berupa laporan tanpa ada yang dirahasiakan dari publik dalam setiap proses pengelolaan keuangan yang dapat dipercayakan kepada organisasi dan ketaatannya pada peraturan perundang-undangan yang berlaku".

\subsection{Partisipasi Anggaran}

Perwujudan partisipasi yaitu suatu tindakan yang turut melibatkan individu secara langsung dan mempunyai pengaruh dalam proes penyusunan anggaran yang dikerjakanya akan diapresiasi atas dasar pencapaian tujuan anggaran. Pengaruh dan andil seseorang turut serta dalam proses penganggaran merupakan wujud partisipasi individu dalam sisi psikologis (Brownell, 1980). Karyawan yang dilibatkan untuk berpartisipasi dalam proses penganggaran menunjukkan adanya interaksi yang baik antara pimpinan dan karyawan (Mada, S., L. Kalangi \& H. Gamaliel 2017).

\subsection{Pengawasan}

Pengawasan adalah penilaian, evaluasi, dan kontrol terhadap keseluruhan proses kegiatan pemeriksaan yang bertujuan agar perencanaan dan pelaksanaan berjalan maksimal dan mencapai tujuan yang telah ditetapkan organisasi (Undang-Undang Nomor 32 Tahun 2004 tentang Pemerintah Daerah). 


\subsection{Hipotesis}

Lembaga-lembaga/organisasi sektor publik diwajibkan untuk lebih menekankan pada pertanggungjawaban horisontal (horizontal accountability) dan pertanggungjawaban vertikal (vertical accountability) karena hal ini merupakan suatu tuntutan akuntabilitas. Akuntabilitas mempengaruhi variabel dependen yaitu kinerja anggaran yang menunjukkan bahwa akuntabilitas yang tinggi dapat meningkatkan kinerja anggaran dalam rangka mencapai tujuan organisasi yang telah ditetapkan (Fernandes and Hanif, 2015). Pertiwi (2015) dalam penelitiannya menyimpulkan bahwa akuntabilitas berpengaruh secara positif dan signifikan terhadap pengelolaan anggaran berbasis value for money.

\section{$H_{1}: \quad$ Akuntabilitas berpengaruh terhadap kinerja anggaran berbasis value for money}

Adanya kebijakan dan kemudahan akses informasi yaitu aspek dari transparansi yang dapat menjangkau setiap aspek kebijakan. Keterbukaan dan kebebasan dalam memperoleh informasi merupakan aspek dasar dari transparansi. Artinya, secara langsung masyarakat dapat mengakses informasi yang berkaitan dengan kepentingan publik (Pasaribu, 2011). Penelitian yang dilakukan oleh Pertiwi (2015) menyatakan bahwa transparansi memiliki pengaruh terhadap kinerja anggaran berbasis value for money pada pengelolaan keuangan daerah dan didukung oleh penelitian Adiwirya and Sudana (2015) yang menyimpulkan bahwa transparansi berpengaruh positif pada kinerja anggaran berbasis value for money.

$\mathrm{H}_{2}$ : Transparansi berpengaruh terhadap kinerja anggaran berbasis value for money

Konteks penganggaran, permasalahan pengukuran kinerja mencakup berbagai macam aspek yang mampu memberikan informasi yang efektif dan efisien terhadap pencapaian kinerja tidak terbatas pada permasalahan penggunaan anggaran. Oleh karena itu, penerapan partisipasi pada organisasi sangat penting guna menyamakan persepsi antara pimpinan dan karyawan (Premananda and Latrini, 2017). Karyawan dilibatkan untuk berpartisipasi dalam proses anggaran yang menunjukkan adanya interaksi yang baik antara pimpinan dan karyawan. Premananda and Latrini (2017) menyimpulkan bahwa partisipasi anggaran berpengaruh positif pada kinerja anggaran berbasis value for money.

\section{$H_{3}$ : Partisipasi berpengaruh terhadap kinerja anggaran berbasis value for money}

Pengawasan merupakan suatu sarana untuk mengontrol kegiatan yang dilakukan dalam sebuah organisasi. Pengawasan juga merupakan bentuk antisipasi pemerintah untuk mencegah terjadinya penyimpangan sehingga kegiatan atau aktivitas pemerintah dapat berjalan dengan baik dan maksimal. Berdasarkan dari peneliti yang dilakukan oleh Wandari, I. D. N. T., Edy Sudjana \& M. P. Adi (2015) menyatakan bahwa terdapat pengaruh variabel pengawasan terhadap variabel kinerja anggaran pemerintah dengan basis value for money dan didukung oleh penelitian Hanafiah, R. R., S. Abdullah \& M. Saputra (2016) bahwa pengawasan intern berpengaruh terhadap pengelolaan keuangan daerah.

$H_{4}$ : Pengawasan berpengaruh terhadap kinerja anggaran berbasis value for money 


\section{Metode Penelitian}

Populasi penelitian adalah institusi/lembaga yang meliputi Sekretariat Daerah, Sekretariat DPRD, Inspektorat, Dinas Daerah, dan Badan Daerah yang berjumlah 29 OPD di Kabupaten Sleman. Teknik pengambilan sampel penelitian ini menggunakan teknik purposive sampling, metode teknik pengambilan sampling ini menggunakan kriteria yang ditentukan oleh penulis. Kriteria untuk responden penelitian yaitu responden memiliki latar belakang pendidikan minimal SLTA, responden memiliki masa kerja minimal 1 tahun dan terlibat dalam penyusunan anggaran.

\section{Definisi Operasional Variabel}

\section{Kinerja Anggaran berbasis Value for Money (Y)}

Ekonomi, efisien, dan efektif merupakan tiga elemen utama pada penerapana pengelolaan anggaran sektor publik. Indikator value for money dibagi menjadi dua bagian, yaitu: (1) indikator alokasi biaya (ekonomi dan efisiensi), dan (2) indikator kualitas kinerja pelayanan (efektivitas). Tiga pokok bahasan dalam value for money (ekonomis, efisien, dan efektif) berkaitan satu dengan yang lain (Fernandes and Hanif, 2015).

\section{Akuntabilitas $\left(\mathbf{X}_{1}\right)$}

Akuntabilitas adalah tindakan pertanggungjawaban untuk mencapai tujuan secara berkala pada pelaksanaan kebijakan pengelolaan potensi sumber daya yang dipercayakan pada suatu organisasi (PP No. 71 Tahun 2010 tentang Standar Akuntansi Pemerintah). Implementasi akuntabilitas diukur melalui indikator yaitu: Ketepatan dan kelengkapan informasi yang berkaitan dengan cara dan aturan untuk mencapai sasaran suatu kegiatan, proses pembuatan suatu keputusan yaitu secara tertulis, tersedia bagi masyarakat yang membutuhkan, dengan setiap keputusan yang diambil sudah memenuhi standar etika dan nilai-nilai yang berlaku, dan sesuai dengan prinsip-prinsip administrasi yang benar, kelayakan dan konsistensi dari sasaran operasional maupun prioritas, kejelasan dari sasaran kebijakan yang telah ditetapkan dan dikomunikasikan penyebarluasan informasi mengenai suatu keputusan melalui media massa, dan kemudahan akses publik pada informasi atas suatu keputusan yang dibuat dan menyusun mekanisme alur pengaduan masyarakat (Adiwirya and Sudana, 2015).

\section{Transparansi $\left(\mathrm{X}_{2}\right)$}

Transparansi berarti keterbukaan pemerintah kepada masyarakat dalam memberikan informasi keuangan yaitu wujud pertanggungjawaban pemerintah (PP No.71 Tahun 2010). Implementasi transparansi diukur melalui indikator yaitu: kemudahan dalam mengakses informasi, penyediaan informasi yang jelas dan mudah dipahami mengenai prosedurprosedur, biaya dan tanggungjawab, menyusun mekanisme alur pengaduan jika terdapat peraturan yang dilanggar atau permintaan pihak tertentu untuk membayar uang suap, dan meningkatkan arus informasi melalui kerjasama dengan media massa dan lembaga non pemerintahan (Adiwirya and Sudana, 2015). 


\section{Pengawasan (X3)}

Pengawasan merupakan suatu proses yang dilakukan oleh pemerintah dalam mengefektifkan kegiatan dan aktivitas pemerintah daerah. Pengawasan dilakukan bertujuan untuk mengawasi, mengevaluasi serta mengontrol kegiatan pemerintah sehingga berjalan dengan baik sehingga sesuai dengan tujuan pemerintah. Variabel pengawasan diukur berdasarkan indikator yaitu, perencanaan dan penyusunan kebijakan, pelaksanaan dan pengendalian kebijakan, pertanggung jawaban dan tujuan (Fernandes and Hanif, 2015).

\section{Partisipasi anggaran (X4)}

Perwujudan partisipasi yaitu suatu tindakan yang turut melibatkan individu secara langsung dan mempunyai pengaruh dalam pross penyusunan anggaran yang dikerjakannya akan diapresiasi atas dasar pencapaian tujuan anggaran (Brownell, 1980). Implementasi partisipasi anggaran diukur melalui indikator berikut ini dari (Hudayah, 2012). Penyampaian usul mengenai format pengawasan anggaran, partisipasi penyusunan arah dan tujuan kebijakan anggaran, permintaan, pendapat dan/atau usulan tentang anggaran berupaya menggali informasi mengenai pelaksanaan anggaran, melaporkan pada pihak pengawas apabila terjadi penyimpangan anggaran, dan sebagai sarana penyampai aspirasi

\section{Hasil dan Pembahasan}

\subsection{Gambaran obyek/subyek penelitian}

Sampel pada penelitian ini adalah Kepala Organisasi Perangkat Daerah (OPD), Bendahara Keuangan, Kepala Bagian Keuangan dan Kepala Bagian Perencanaan pada Organisasi Perangkat Daerah (OPD) di Kabupaten Sleman. Kuesioner yang dibagikan pada 29 Organisasi Perangkat Daerah (OPD) di Kabupaten Sleman sebanyak 116 kuesioner dengan tingkat pengembalian $87,06 \%$ yaitu sebanyak 101 kuesioner. Kuesioner yang tidak kembali yaitu 15 kuesioner $(12,94 \%)$.

Tabel 1: Deskripsi responden berdasarkan gender

\begin{tabular}{cccc}
\hline No. & Gender & Jumlah & Prosentase \\
\hline 1 & Laki-laki & 41 & $40,60 \%$ \\
2 & Perempuan & 60 & $59,40 \%$ \\
\hline
\end{tabular}

Sumber: Data primer diolah pada tahun 2019

\subsection{Uji Validitas}

Uji validitas digunakan untuk mengukur valid dan tidaknya suatu kuesioner. Kuesioner dikatakan valid jika pertanyaan mampu mengungkapkan sesuatu yang diukur. Uji validitas diukur menggunakan pearson corelation. Jika tingkat probabilitas koefisien $\alpha<0,05$ maka pertanyaan pada kuesioner tersebut disebut valid. 
Tabel 2: Hasil uji validitas variabel akuntabilitas

\begin{tabular}{ccc}
\hline Instrumen & Pearson Correlation & Keterangan \\
\hline Instrumen X1.1 & 0,000 & Valid \\
Instrumen X1.2 & 0,000 & Valid \\
Instrumen X1.3 & 0,000 & Valid \\
Instrumen X1.4 & 0,000 & Valid \\
Instrumen X1.5 & 0,000 & Valid \\
Instrumen X1.6 & 0,000 & Valid \\
Instrumen X1.7 & 0,000 & Valid \\
Instrumen X1.8 & 0,000 & Valid \\
Instrumen X1.9 & 0,000 & Valid \\
Instrumen x1.10 & 0,000 & Valid \\
\hline
\end{tabular}

Sumber: data primer diolah tahun 2019

\subsection{Uji Reliabilitas}

Tabel 3: hasil uji reliabilitas

\begin{tabular}{ccc}
\hline Variabel & Cronbach Alpha & Keterangan \\
\hline Akuntabilitas & 0,772 & Reliabel \\
Transparansi & 0,627 & Reliabel \\
Partisipasi & 0,873 & Reliabel \\
Pengawasan & 0,681 & Reliabel \\
\hline
\end{tabular}

Sumber: data primer yang diolah tahun 2019

Hasil uji reliabilitas diatas dapat disimpulkan bahwa kuesioner dari keempat variabel independen akuntabilitas, transparansi, partisipasi, dan pengawasan yaitu reliabel. Dikarenakan nilai Cronbach Alpha pada setiap variabel yaitu lebih besar dari 0,6.

\subsection{Uji Hipotesis}

Tabel 4: Hasil uji hipotesis

\begin{tabular}{ccccc}
\hline Variabel & $B$ & $\mathrm{t}$ & \multicolumn{1}{c}{ Sig. } & Ket \\
\hline Akuntabilitas & 0,271 & 2,186 & $0,031^{*}$ & $\mathrm{H}_{1}$ : Diterima \\
Transparansi & 0,338 & 3,265 & $0,002 *$ & $\mathrm{H}_{2}$ : Diterima \\
Partisipasi & 0,617 & 4,932 & $0,000^{* *}$ & $\mathrm{H}_{3}$ : Diterima \\
Pengawasan & 0,198 & 1,076 & 0,285 & $\mathrm{H}_{4}$ : Ditolak \\
\hline F hitung & 32,272 & & $0,000^{* *}$ & \\
Adjusted $R$ Square & 0,556 & & & \\
\hline
\end{tabular}

Keterangan: * sig < 5\%; ** sig < $1 \%$

Berdasarkan hasil uji hipotesis dapat disimpulkan bahwa nilai signifikansi 0,031 $<0,05$ pada variabel independen akuntabilitas sehingga $\mathrm{H}_{1}$ diterima, variabel transparansi memiliki nilai $0,002<0,05$ sehingga $\mathrm{H}_{2}$ diterima, serta variabel partisipasi memiliki nilai signifikansi $0,000<0,05$ sehingga $\mathrm{H}_{3}$ diterima, sedangkan satu variabel independen yaitu pengawasan memiliki nilai signifikansi 0,285 yang berarti bahwa variabel tersebut tidak berpengaruh. 


\section{Akuntabilitas berpengaruh terhadap kinerja anggaran berbasis value for money}

Penelitian ini sejalan dengan hasil penelitian yang dilakukan oleh Nababan, Sihombing, \& Thamrin (2018) menjelaskan bahwa tingkat akuntabilitas meningkat maka kualitas kinerja pengelolaan anggaran juga semakin meningkat. Perwujudan penerapan prinsip Good Corporate Governance yang telah dilakukan instansi pemerintah pusat maupun daerah sebagai aspek dasar penilaian dari masyarakat apakah kinerja instansi pemerintah sesuai dengan prinsip value for money. Hasil kinerja pengelolaan anggaran yang baik membutuhkan pertanggungjawaban secara efisien, efektif, dan ekonomis. Hal ini sejalan dengan konsep akuntabilitas pada pengelolaan anggaran berbasis value for money yang dapat dikatakan baik apabila saling berkaitan satu sama lain (Sudewi, Herawati, Yuniarta 2017).

\section{Transparansi berpengaruh terhadap kinerja anggaran berbasis value for money}

Terciptanya pemerintahan daerah maupun pusat yang bersih, efektif, akuntabel, dan peduli terhadap kepentingan masyarakat merupakan terwujudnya transparansi yang horizontal accountability. Kepentingan masyarakat menjadi hal pokok yang harus diutamakan (Kautsar, Andirfa, \& Rahman, 2018). Transparansi berperan sebagai kontrol atas kinerja yang dilakukan pemerintah. Dalam menentukan arah keberhasilan proses pelaksanaan anggaran dibutuhkan kebijakan dalam proses penyusunan anggaran yang telah ditetapkan oleh pemerintah sehingga semakin transparan kebijakan yang dilaksanakan maka akses informasi terkait laporan pertanggungjawaban semakin terbuka dan dapat dengan mudah diketahui publik (Purnomo \& Putri, 2018).

\section{Partisipasi berpengaruh terhadap kinerja anggaran berbasis value for money}

Karyawan diberikan kesempatan untuk turut berpartisipasi dalam proses penyusunan anggaran guna menunjukkan kemampuan dalam melaksanakan tugasnya sehingga dapat memperlancar organisasi dalam mencapai tujuan. Timbulnya rasa tanggung jawab dan dorongan kreatifitas menjadi bentuk partisipasi karyawan pada proses penyusunan anggaran (Hidrayadi \& Savitri, 2016). Tanggung jawab aparat pemerintah terhadap masing-masing tugasnya dapat didorong karena diikursertakan dalam proses penyusunan anggaran agar mampu mencapai tujuan yang ingin dicapai (Rahayu, Sulindawati, \& Sinarwati, 2014).

\section{Pengawasan berpengaruh terhadap kinerja anggaran berbasis value for money}

Penelitian ini sejalan dengan hasil penelitian Pratama (2015) yang menjelaskan bahwa apabila proses penyusunan anggaran tidak dikontrol dengan baik maka akan terjadi permasalahan serta biaya-biaya akan terbuang dan tidak terserap secara penuh sebagaimana mestinya. Pengawasan alangkah lebih baik apabila mampu melaksanakan tugas pokoknya sesuai dengan fungsinya yang bertujuan untuk mengurangi serta mencegah penyimpangan. Sistem pengawasan yang baik yang dimiliki pemerintah diharapkan mampu mengarahkan tugas bawahannya dengan tepat agar mampu meningkatkan kualitas kinerja pemerintah sehingga terhindar dari penyimpangan-penyimpangan maupun penyelewengan. Tujuan jangka panjang kebijakan pengawasan untuk mengantisipasi pada tindakan pencegahan, dan perbaikan sistem pengawasan internal maupun eksternal. Tujuan jangka pendek yaitu mampu memberantas seluruh kegiatan penyebab timbulnya pemborosan anggaran. Cara ini 
dinilai efektif untuk mengurangi terjadinya penyimpangan dalam penggunaan anggaran belanja publik (Wiguna, Yuniarta, Darmawan 2015).

\section{Kesimpulan, keterbatasan \& saran}

Hasil analisis data yang dilakukan dapat disimpulkan bahwa, pertama: akuntabilitas, transparansi, dan partisipasi memiliki pengaruh terhadap variabel kinerja anggaran, kedua: pengawasan tidak berpengaruh terhadap variabel dependen yaitu kinerja anggaran berbasis value for money atas pengelolaan keuangan daerah. Penelitian ini memiliki keterbatasan yaitu hanya memasukkan 4 dari 9 prinsip Good Corporate Governance sebagai variavel independen. Prinsip yang digunakan pada penelitian ini yaitu akuntabilitas, transparansi, partisipasi, dan pengawasan. Sedangkan, masih ada 5 prinsip Good Corporate Governance yaitu daya tanggap, profesionalisme, kesetaraan, kewajaran, wawasan kedepan, dan prinsip hukum. Keterbatasan lain peneltian ini adalah hanya menggunakan motede penyebaran kuesioner dan tidak menggunakan metode lain dalam pengumpulan data.

Dalam upaya memperbaiki dan meningkatkan penerapan kinerja anggaran berbasis value for money, peneliti memberikan saran yaitu:

1. Bagi peneliti selanjutnya agar menambah atau mengganti dengan prinsip Good Corporate Governance lain yang sebelumnya belum pernah diteliti.

2. Agar penelitian dapat menjadi lebih baik, untuk penelitian selanjutnya menambahkan teknik wawancara sehingga peneliti dapat memperoleh jawaban ssecara langsung dan sesuai dengan yang diharapkan.

\section{DAFTAR PUSTAKA}

Adiwirya, M. F. and I. P. Sudana (2015). Akuntabilitas, Transparansi, dan Anggaran Berbasis Kinerja pada Satuan Kerja Perangkat Daerah Kota Denpasar. E-Jurnal Akuntansi 11(2): 611-628..

Arifani, C., A. Salle \& A. Rante. (2018). Pengaruh Akuntabilitas, Transparansi dan Pengawasan terhadap Kinerja Anggaran Berbasis Value For Money. Jurnal Akuntansi dan Keuangan Daerah 13(1): 68-82.

Arista, A. S. A. N. and I. W. Suartana (2016). Pemahaman Atas SAP Sebagai Pemoderasi Pengaruh Akuntabilitas dan Transparansi pada Kinerja Anggaran SKPD Kota Denpasar. E-Jurnal Akuntansi 17(2): 1667-1699.

Basri, H. and A. S. Nabiha (2016). Accountability of local government: The case of Aceh Province, Indonesia. Asia Pacific Journal of Accounting and Finance 3(1): 1-14.

Brownell, P. (1980). Participation in the budgeting process: When it works and when it doesn't. the accounting review 56(4): 844-860.

Fernandes, W. and R. A. Hanif (2015). Pengaruh Akuntabilitas, Transparansi dan Pengawasan terhadap Kinerja Anggaran pada Pemerintah Daerah Kabupaten Kampar. Jurnal Online Mahasiswa Fakultas Ekonomi Universitas Riau 2(2): 1-13.

Ghozali, I. (2018). Aplikasi Analisis Multivariat dengan Program SPSS. Badan Penerbit Universitas Diponegoro. Semarang.

Hanafiah, R. R., S. Abdullah \& M. Saputra (2016). Pengaruh Akuntabilitas, Transparansi, Kapasitas Sumber Daya Manusia, dan Pengawasan Intern terhadap Pengelolaan Keuangan Daerah (Studi Di SKPK Pemerintah Kabupaten Aceh Utara). Jurnal Administrasi Akuntansi: Program Pascasarjana Unsyiah 5(4): 77-86. 
Hidrayadi, R., \& E. Savitri (2016). Pengaruh Desentralisasi, Partisipasi Anggaran, Komitmen Organisasi, dan Motivasi Kerja terhadap Kinerja Manajerial SKPD Kota Pekanbaru. Jurnal Online Mahasiswa (JOM) Bidang Ilmu Ekonomi, 2(2), 1-15.

Hudayah, S. (2012). Pengetahuan Anggaran, Efektivitas Partisipasi dan Akuntabilitas dalam Hubungannya dengan Kepuasan Atas Pelaksanaan Anggaran Berbasis kinerja Pengetahuan Anggaran, Efektivitas Partisipasi dan Akuntabilitas dalam Hubungannya dengan Kepuasan. Jurnal Borneo Administrator 8(1): 50-74.

Husaini, H. and L. Lisnawati (2013). Analisis Pengaruh Akuntabilitas dan Transparansi Pengelolaan Keuangan Daerah terhadap Kinerja Pemerintah Daerah. FAIRNESS $3(1): 23-40$.

Jayanti, I. P. (2014). Reformasi Pengelolaan Keuangan Daerah dalam Rangka Mewujudkan Transparansi dan Akuntabilitas (Studi pada Pemerintah Kota Malang). Jurnal Administrasi Publik 2(2): 300-305.

Karacan, E. and K. Yazici (2015). Performance-Based Budget Arrangements, the Implementation Process and Advancements in Turkey. International Journal of Business and Social Science 6(4): 62-79.

Kautsar, M., M. Andirfa \& B. Rahman (2018). Pengaruh Transparansi dan Akuntabilitas terhadap Peningkatan Kinerja Pengelolaan Pajak Daerah pada Dinas Pengelola Keuangan dan Aset Daerah (DPKAD) Kota Lhokseumawe. Jurnal Akuntansi dan Pembangunan (JAKTABANGUN) STIE Lhokseumawe, 3(2), 69-81.

Mada, S., L. Kalangi \& H. Gamaliel (2017). Pengaruh Kompetensi Aparat Pengelola Dana Desa, Komitmen Organisasi Pemerintah Desa, dan Partisipasi Masyarakat terhadap Akuntabilitas Pengelolaan Dana Desa di Kabupaten Gorontalo. Jurnal Riset Akuntansi dan Auditing "Goodwill", 8(2).

Nababan, R. A., M. Sihombing \& H. Thamrin (2018). Pengaruh Akuntabilitas dan Transparansi, terhadap Pengelolaan Keuangan Berkonsep Value For Money pada Pemerintah di Kabupaten Dairi. Anthropos: Jurnal Antropologi Sosial dan Budaya (Journal of Social and Cultural Anthropology), 4(1), 108-120.

Pasaribu, F. J. (2011). Pengaruh penyajian laporan keuangan SKPD dan aksesibilitas laporan keuangan SKPD terhadap Transparansi dan Akuntabilitas Pengelolaan Keuangan SKPD. Tesis

Peraturan Pemerintah Nomor 58 Tahun 2005 Tentang Pengelolaan Keuangan Daerah.

Peraturan Pemerintah Republik Indonesia No. 71 Tahun 2010/SAP

Pertiwi, D. P. (2015). Pengaruh Akuntabilitas, Transparansi, dan Pengawasan terhadap Pengelolaan Anggaran Berkonsep Value For Money pada Instansi Pemerintah (Studi Empiris SKPD Provinsi Riau). Jurnal Jom FEKON 2 (2) 2(2): 1-15.

Pratama, D. (2015). Pengaruh Pengangaran Berbasis Kinerja, Pengawasan Preventif dan Pengawasan Detektif terhadap Efektifitas Pengendalian Anggaran (Studi Empiris pada Satuan Kerja Perangkat Daerah di Kabupaten Pelalawan). Jurnal Online Mahasiswa (JOM) Bidang Ilmu Ekonomi, 1(2), 1-15.

Premananda, N. L. P. U. \& M. Y. Latrini (2017). Pengaruh Akuntabilitas, Transparansi, dan Partisipasi Anggaran terhadap Kinerja Anggaran pada Pemerintah Kota Denpasar. E-Jurnal Akuntansi 18(3): 2451-2476.

Purnama, F., \& N. Nadirsyah (2016). Pengaruh Pengawasan Keuangan Daerah, Akuntabilitas, dan Transparansi Pengelolaan Keuangan Daerah terhadap Kinerja Pemerintah Daerah pada Kabupaten Aceh Barat Daya. Jurnal Ilmiah Mahasiswa Ekonomi Akuntansi, 1(2), 1-15. 
Purnomo, B., \& Putri, C. (2018). Akuntabilitas, Transparansi, Pengawasan dan Kinerja Anggaran Berkonsep Value For Money. Jurnal Riset Akuntansi dan Keuangan, 6(3), 467-480.

Rahayu, N. L. S., N. L. G. E. Sulindawati \& N. K. Sinarwati (2014). Pengaruh Partisipasi Penyusunan Anggaran, Kualitas Sumber Daya Manusia (SDM), dan Penerapan Sistem Informasi Akuntansi terhadap Kinerja Pemerintah Daerah. JIMAT (Jurnal Ilmiah Mahasiswa Akuntansi) Undiksha, 2(1).

Rawlins, B. R. (2008). "Measuring the relationship between organizational transparency and employee trust." public relation journal 2(2): 1-21.

Sudewi, K. N., N. T. S. Herawati \& G. A. S Yuniarta (2017). Pengaruh Akuntabilitas, Transparansi, Komitmen Organisasi, dan Pengawasan terhadap Pengelolaan Anggaran Berkonsep Value For Money pada Satuan Kerja Perangkat Daerah (SKPD) Kabupaten Buleleng. JIMAT (Jurnal Ilmiah Mahasiswa Akuntansi) Undiksha, 8(2).

Undang- undang Nomor 32 Tahun 2004 Tentang Pemerintah Daerah Diatur Pengawasan yang Bersamaan dengan Pembinaan. (2004). Jakarta: Republik Indonesia.

Wandari, I. D. N. T., Edy Sudjana \& M. P. Adi (2015). Pengaruh Akuntabilitas, Transparansi, Ketepatan Waktu dan Pengawasan Internal terhadap Kinerja Anggaran Berkonsep Value For Money pada Instansi Pemerintah di Kabupaten Buleleng. JIMAT (Jurnal Ilmiah Mahasiswa Akuntansi) Undiksha 3(1): 1-12.

Wiguna, M. B. S., G. A S. Yuniarta \& N. A. S Darmawan (2015). Pengaruh Pengawasan Keuangan Daerah, Akuntabilitas dan Transparansi Pengelolaan Keuangan Daerah terhadap Kinerja Pemerintah Daerah Kabupaten Buleleng. JIMAT (Jurnal Ilmiah Mahasiswa Akuntansi) Undiksha, 3(1), 1-12. 